\title{
Creating a Core Innovation Capability in Airbus
}

\author{
Hyeonjoo Kim \\ Correspondence: Hyeonjoo Kim, Coventry University, UK. \\ Received: July 5, 2021 \\ doi:10.11114/bms.v7i3.5317 \\ Accepted: July 27, 2021 \\ Online Published: August 5, 2021 \\ URL: https://doi.org/10.11114/bms.v7i3.5317
}

\begin{abstract}
Flight in modern age caused our society more global than that of past age. People can go to school aboard, go to work aboard, and travel aboard with airplanes. Airplane has changed our society. Airplane manufacturing industry requires sophisticated technology and innovative management. This most intelligent industry's innovation strategy can be one of epitomes for business strategy. Airplane manufacturing can be one long-term oriented business. Airplane industry requires many different fields of study not only natural science, but also social science. To manage both engineering team and management team, significant organization strategy could be one crucial factor to maintain its organization effective. Airplane industries must innovate to offer more reliable service with safety, low price and fast travel. New version of motor, car, aircraft and TV takes usually high system level and incremental innovation. Airbus is one of leading aircraft manufacturer and its market share is second largest globally. This study would bring about understanding of innovation management at highest technology and cutting-edge industry.
\end{abstract}

Keywords: Innovation 4P, Incremental Innovation, Innovation Management, International Management

\section{Objectives of Study}

1. To identify and examine the key elements of relevant theory

2. To critically analyze and evaluate the constructs / models

3. To integrate of theoretical innovation management models into the analysis

4. To provide a critical discussion to the market conditions question

\section{Introduction}

Airbus is one of leading company in aerospace industry and it is the biggest aeronautics and space company with 133,782 employees in Europe. The firm manufactures most innovative commercial airplane and largest amount of helicopter around the world. It has also considerable knowledges in military airplane, cyber security and satellite (Airbus website, 2017).

Airbus S.A.S which located in Blagnac, France is a subsidiary company of Airbus Group. The company produces commercial aircraft and had supplied to airline companies such as Lufthansa, Emirates, Air France-KLM, British Airways, United Airlines, Qantas and Cathay Pacific (MarketLine, 2014).

Airbus Group NV which located in Leiden, the Netherlands is formerly European Aeronautic Defence and Space company (EADS N.V.). Main product of the firm is civil and military helicopter. The company has special mission to approach military airplane (MarketLine, 2014).

Airbus Group SE which located in Leiden, the Netherlands is previously Airbus Group NV (MarketLine, 2015).

Airbus's industry mainly has been focused on four products such as commercial airplane, helicopters, space and defense. The firm is no.1 helicopter supplier to world market. It provides satellites and other space solution. As well as cyber security service has been added to Airbus's business (Airbus website, 2017). 


\section{Business Model of Airbus}

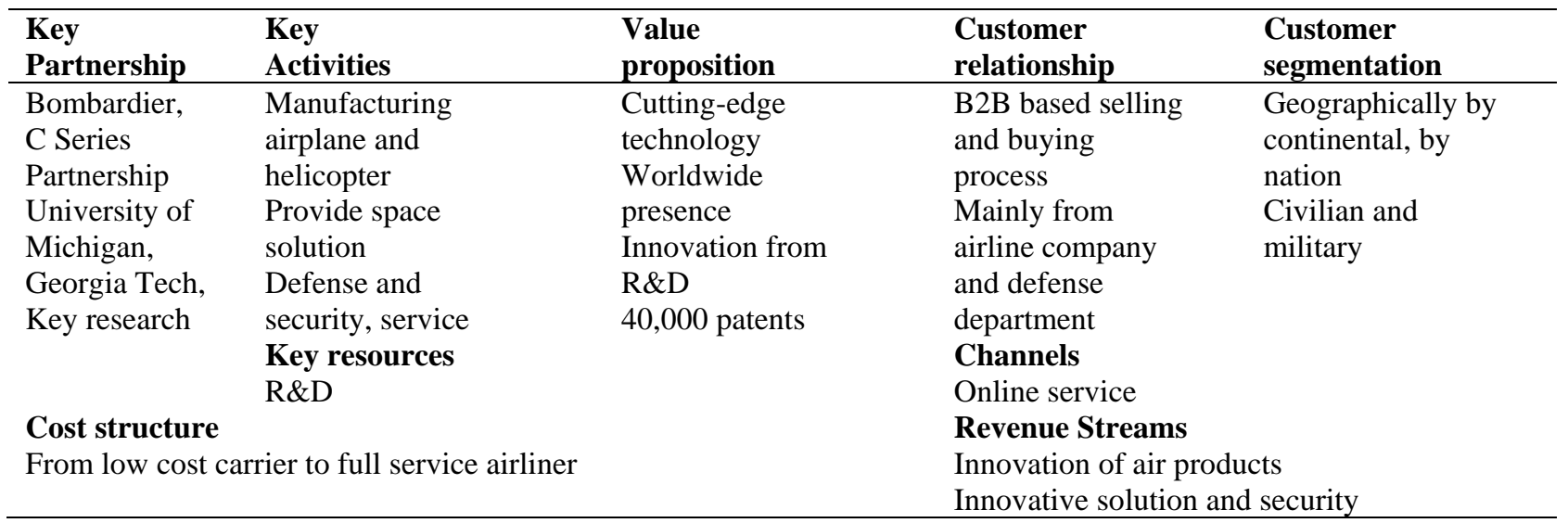

Figure 1. Business model canvas of Airbus

Airbus is not simple organization and it is very complicated organization which produces cutting-edge technology. Airbus is one of most innovative companies in the world with analysis of business model. The company has R\&D department and it innovates most efficient flight and has future oriented management. The firm is second largest aerospace provider in the word and it has been globally recognized (Airbus website, 2017).

- Airbus is focused on research for innovation. Partnership with University of Michigan and Georgia

Tech for research and internal department of R\&D as firm's key resource indicates that research and development is crucial innovation for Airbus. This encourages Airbus's product improvement.

- Airbus's cyber security innovation has growth in emerging market and boosts security options for national infrastructure. It provides protection to the system and environment which deliver decent position for the firm and these activities causes key area of concentration of the company (Warwick Ashford, 2017).

- Airbus owns approximately 40,000 patents and it delivers tremendous power on innovation of aerospace technology. More patents can be interpreted as competitive advantage in the market.

- Airbus deals with both civilian business and government official such a military or defense department. To avoid economy downturn, it is positive aspect for firm revenue.

- $\quad R \& D$ department of Airbus gives most innovation in aerospace technology. The industry where the company involved requires most advanced science and technology.

\section{Airbus's Segmentation, Targeting and Positioning}

Table 1. Airbus's Segmentation, Targeting and Positioning

\begin{tabular}{ll}
\hline Segment & Aerospace and cyber security \\
Target Group & Airliner and Defense department \\
Positioning & Global presence, research partnership, manufacturing in other continentals \\
\hline
\end{tabular}




\section{Product Portfolio}

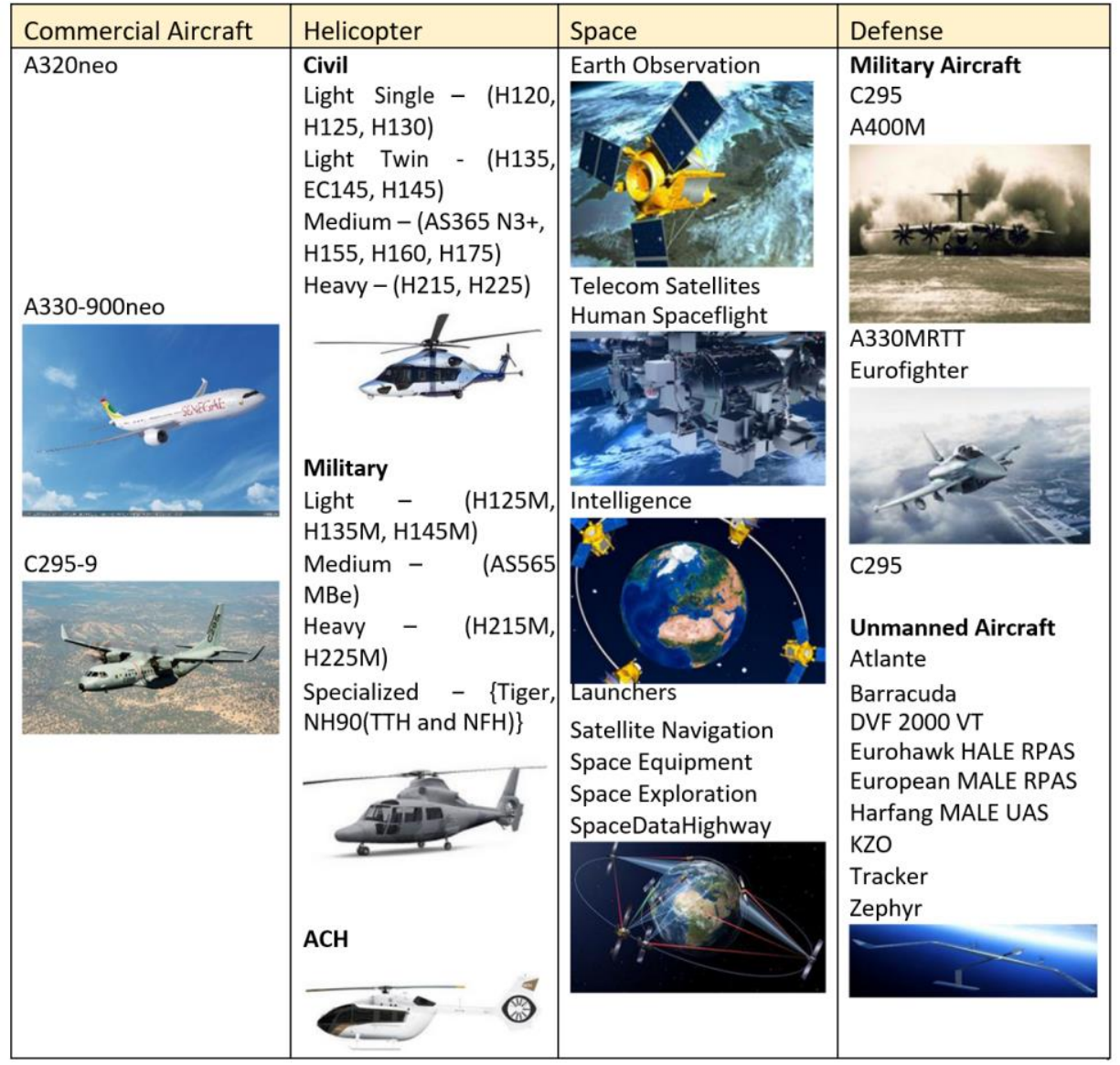

\section{Target Customers}
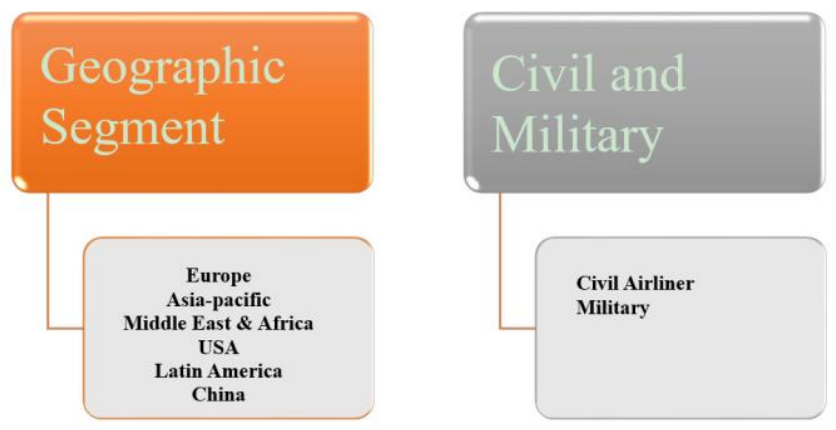

Figure 2. Segmentation strategy of Airbus 


\section{Innovation Dimension Framework (4 Ps)}

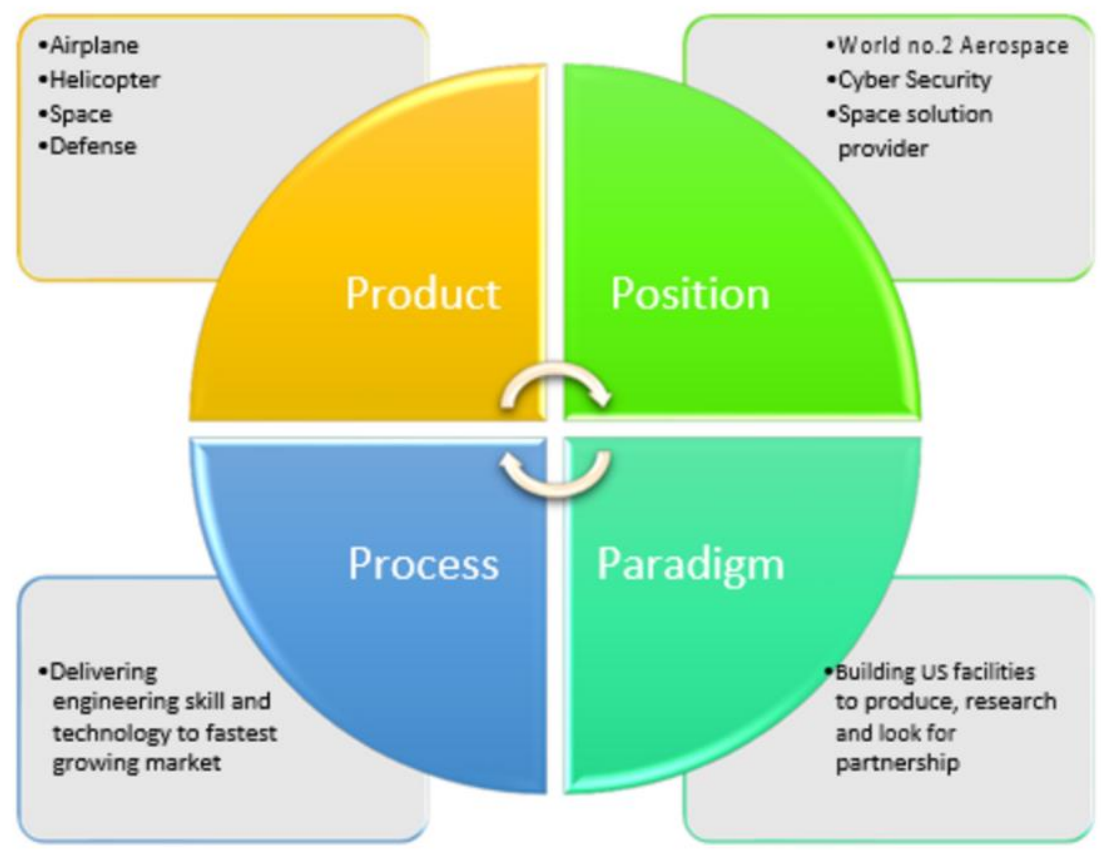

Figure 3. Innovation dimensions (4 Ps)

\section{- Product of Airbus}

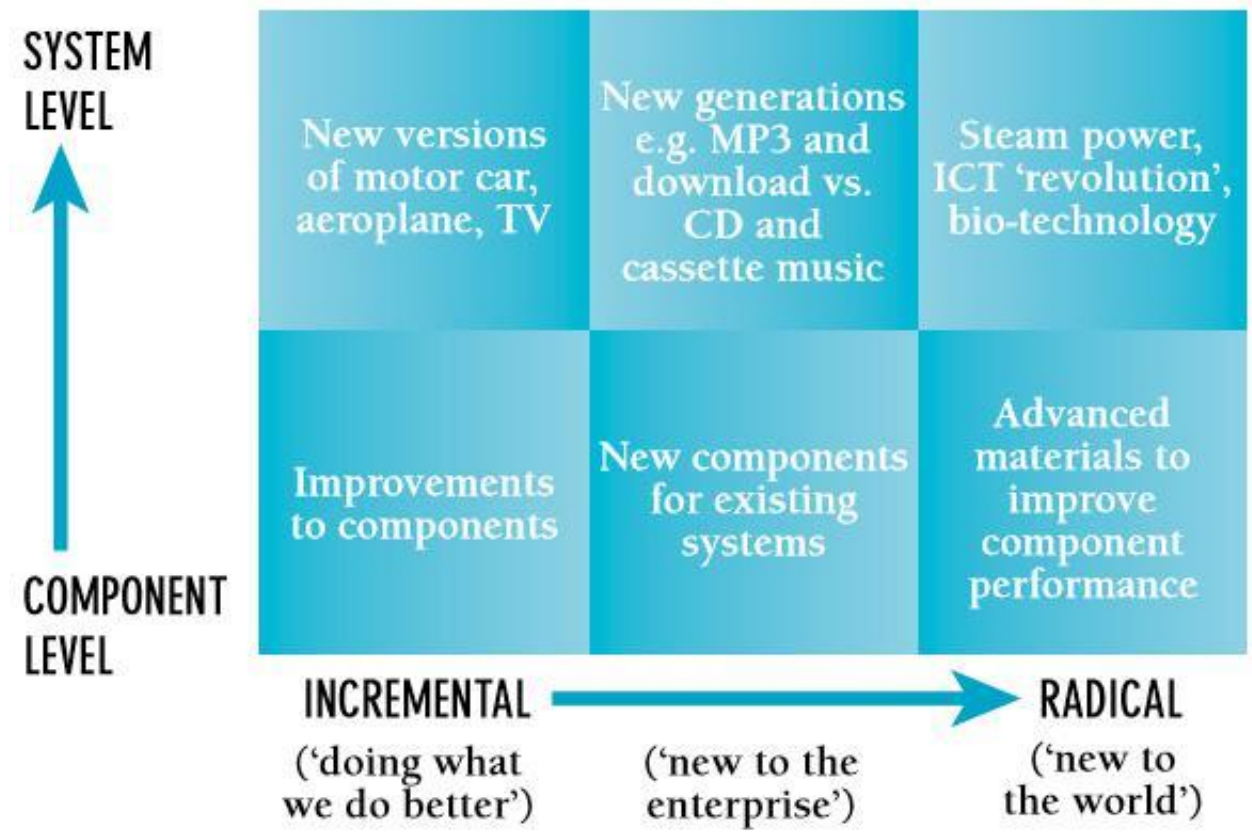

Figure 4. Dimension of Innovation (Joe Tidd et al, 2005)

As figure 4 above indicates that aeroplane's product innovation is system level and incremental. On December 1, 2010, Airbus introduce replace of engine for A320. A320neo has 15\% higher fuel saving engine than that of A320 and it carries lower noise and $\mathrm{CO} 2$ emission than previous products. It has larger window installed for better view in the sky (BERNSTEIN RESEARCH).

\section{- Process of Airbus}


China is one of fastest growing economy region and Chinese air travel has sky-rocketed. The MoU (Memorandum of Understanding) was agreed by Airbus COO and president of Commercial Aircraft and He Lifeng, chairman of the Chinese National Development and Reform (NDRC) in Berlin, Germany. This agreement could deliver support for engineering skill and technology innovation and encourage Chinese suppliers. This action could help faster airport stand-by time for airbus and safer air travel (MATT DRISKILL, 2017).

\section{- Position of Airbus}

Airbus became second largest aerospace manufacturer in the world. However, the firm's position expands to cyber security field. Airbus's new field as cyber security protects society and improves infrastructure (Warwick Ashford, 2017).

Traditionally known as aircraft supplier, Airbus entered space industry with previously achieved aerospace technology. The company's position as aircraft manufacturer has been expanded to space science and technology solution provider (Airbus website, 2017).

Airbus engineers designed sailing yacht is in top racing. The company produces yacht and it is world's fastest yacht. The firm's aerodynamic technology can be applied to boat and sea sport technology. Airbus expanded its position to the ocean (KAREN WALKER, 2017).

\section{- Paradigm of Airbus}

First airplane was created and flown in the United States and the nation has Boeing that is the world best airplane manufacturer with a century of history. US military service is known to be world most powerful military. However, Airbus is later comer to aerospace industry and the company entered US which is most competitive market for aerospace industry. Facility at the Mobile Aeroplex in Brooklyn produces and supplies to US airliners such as JetBlue and Delta Airline. The company had built the research center and welcomes US colleges and researchers. This type of innovation is significant radical management (MARK AREND, 2017).

A bottom-up approach at work place is significant innovation which leader can listen all information from workers and have understanding from it. 10 people working on culture change, the methods and tool and support for innovation, 10 people working as project leaders, and 5 people working with startups are corporate innovation for conduct teams at work place (Hype Case Study).

\section{Evaluation of Components of Innovative Organization with Airbus}

To integrate of theoretical innovation management models into the analysis of Airbus, there are seven factors for analysis.
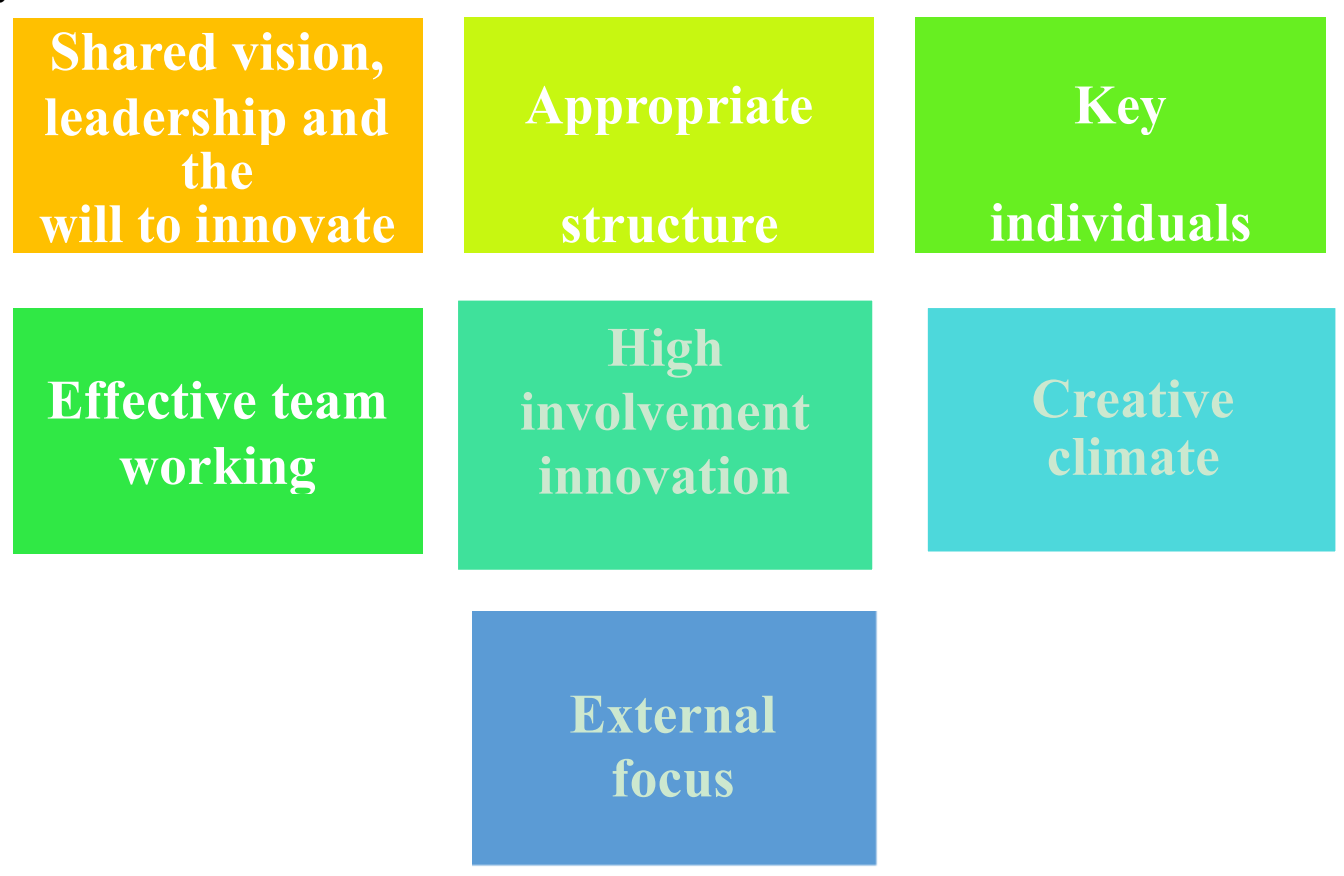

Figure 5. Components of Innovation organization (Joe Tidd et al, 2005) 


\section{Shared vision, leadership and the will to innovate}

Airbus's vision has 3 most focused sections such as global charitable actions, dedicating firm's resources to effective partnerships with volunteer associations and global aid organizations for better world. The company supports the humanitarian societies and aiding young groups. The company's vision is to encourage international organization and young group development through contact with the aerospace industry and this will help the firm reach lager populations.

Airbus R\&D has concentration on electrification, urban air mobility, design \& digital factory, connected fleet and new business models to response with dramatic technology shifting in the market place. In fact, there new electric car coming out in the market and green movement is big issue. Connected fleet will allow passengers to access to internet and long-distance calling (Airbus website, 2017).

\section{Appropriate structure}

Airbus has two difference bases. Base in France has commercial aircraft manufacturing focused structure and other base in the Netherlands has focused on civil and military helicopter and military technologies. Both Airbus S.A.S and Airbus SE has tremendous innovation source which is delivered by R\&D department. Research centers in EU and US have strong roles in the company (MarketLine, 2014).

\section{- Key individuals}

Bruno Gutierres is a head of Airbus Bizlab that is Paris based startup company. Airbus's management encourages its startup business by Airbus which is expected to deliver tremendous advantage for the company in the future. This program encourages Airbus ProtoSpace, own network of innovation facilities and Airbus Venture.

Paul Eremenko, Airbus CTO (Chief Technology Officer) leads innovation and improves ecosystem. He previously led company's A4 innovation center. He worked for world most innovated organizations such as Google, Motorola, DARPA, the Pentagon's research agent (Airbus website, 2017).

\section{Effective team working}

Airbus US does not suffer labor shortage at Brooklyn facilities. Many labors were selected from certain categories such as STEM (Science, technology, engineering and math) fields degree achievers and US military veterans. Tremendous knowledge in science and technology and viable experience in real battle filed are significant factors for innovation. These workers are highly expected to improve both product and process innovation (MARK AREND, 2017).

\section{- High involvement innovation}

R\&D delivers Airbus with tremendously effective way to influence on specialization in each sector and each location. R\&D has one of most crucial role in Airbus. The firm invites the platform team for meetings and it is for observe project process and production tooling and improve support of service for design of engineering and management system (MARIE-CHRISTINE MONNOYER et al, 2007).

\section{- Creative climate}

Aerospace industry requires tremendous knowledge, pre-experience and experiment due to air travel carries human lives in the skies. To survive in current aerospace market, innovation management is

required for firm's performance. Airbus's creative projects such as electrification enhances green technology and connected fleet improve both navigation and passenger's amenities. As well as WTO claims Settlement procedure on EU subsidies on Airbus which is political influence drives firm's creative and innovative management and movement (Wolfgang Maennig et al, 2010).

\section{- External focus}

Growing Chinese air travel demand is positive aspect for Airbus. Third most popular airline is China Southern and it carried more than 100 million passengers globally in 2014. Only 5\% of all population hold passport in 2014 and the expectation is growing of more air travel. This is big opportunity for Airbus (Jenny Southan, 2016). Airbus is largest in $\mathrm{EU}$ and it is recognized around world with global presence.

\section{Discussion to the Market Conditions Question}




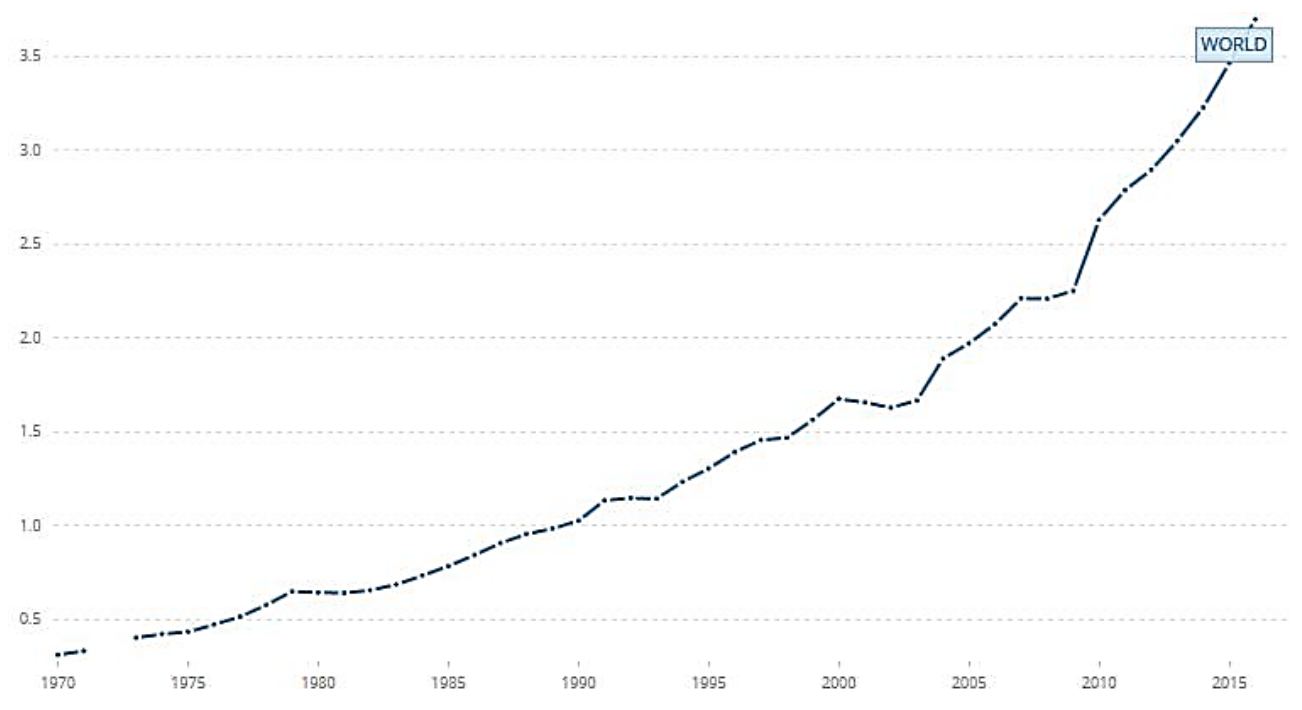

Figure 6. World Bank, 2017 - Air transport, passenger carried

Since airliners were introduced to the world market, air travel keeps growing and recently it is sky-rocketing which can be interpreted as green light for aircraft manufacturers.

- Competition with no. 1 manufacturer, Boeing

Boeing is traditional aircraft manufacturer and the company is leading manufacturer in the world. Airbus's A320neo and Boeing's 7series have competition in the market place. After A320neo engine introduced in the market, Airbus is leading. After introducing 737-900ER, Boeing sales has risen (BERNSTEIN RESEARCH).

\section{- Military conflict}

According to news media, recently Saudi Arabia declared war on Lebanon. This kind of military conflict will bring about rising demand for not only military helicopter, but also military related industries. For Airbus, this conflict can be one major opportunity to expand firm revenue.

\section{- China's growing and emerging market}

China has world biggest population and second largest economy. Corresponding with growth, air travelling is rising. China Southern ordered 20 A350 XWBs and Airbus provided 100th XWB to China Airlines. Chinese market is tremendously attractive with expectation of growth of air travel (AsianAviation, 2017).

\section{- Rising international destination and domestic flights forecast}

IATA (International Air Transport Association) announced that there will be 31\% higher demand for airline in 2017. Uzbekistan expected to be fastest growing traffic for international passenger and United Arab Emirates expected to host 29.2 million air passengers. For domestic air trip growth, Brazil and Turkey are expected to have highest growth. All continental by regions will have growing airline demands (IATA, 2017).

\section{- Low priced air travel - Ryan Air and Easy Jet}

It is not difficult to meet people who are looking for Ryan Air schedule nowadays. Air travel became popular and simple. These airliners take routes on mid-sized airports such as Billund and other airports around small cities. This business strategy to penetrate current market place might cause more demand on aircrafts.

\section{Conclusion}

Airbus is a leading aerospace company in the world and has title of no. 1 in EU. Corresponding to current cutting-edge science and technology in the market place, the company has innovated management and products.

Airbus's innovation management leads rising of internal startup company to induce more efficiency for entire organization. This can be dramatic process of innovation management.

The company highly focused on innovation for product. The firm always has competition from other global manufacturers. Technology updates on aircraft must be crucial factor for appearance to customers. Boeing's 7 series has 
innovation for technology updates and Airbus also has too.

Airbus's cutting-edge science and technology for commercial and military products can deliver positive solution for space mission. The company offers space solution and it already practiced and gained knowledge by doing its business. This positioning innovation brought about space technology for next generation.

Airbus's cyber security can provide safety for our infrastructures and individual. This protects our system as well as provides better solution for navigation and on-board service for Airbus passengers.

Innovation in Airbus is system oriented and incremental process. It is high cost and knowledge based process with massive infrastructure which cannot be dramatic innovation process but it is suitable for incremental innovation process. Airbus innovation process takes on system level, not component level. It is tremendously sophisticated industry. One part of aircraft changes would be whole change of entire process in production process. System level of innovation process is suitable for Airbus.

\section{Recommendations}

Analysis of innovation dimension, components of innovation organization and market condition delivered significant understanding on Airbus.

\section{- Product Aspects}

While air-traveling, usual passenger experience uncomfortable with seat. Flights are still not enjoyable caused by lack of wi-fi. Upgrades of internal design would encourage Airbus presence.

\section{- Process dimension}

It is difficult to observe weather Airbus is selling or buying. It maybe military styled buying process which is under confidential process. However, clear buying and report process would bring more reliable image to brand value.

\section{- Positioning dimension}

Airbus US must be very effective way to innovate entire company. Experienced military veteran would be strong key elements for Airbus.

China also has tremendous power in military with rising economy and industrial sector which can increase level of innovation of Airbus.

Personal experience and knowledge of aircraft and security from military highlight that military has more dynamic approach to innovation of air travel. Positioning for security sector for private sector would be reasonable.

\section{- Paradigm dimension}

Our generation is going into green management and connected system. Airbus's green technology for flight would be major impact in current market place and connected system would bring about more reliable flight and safer flight as well as more enjoyable flight for passenger. New management for offering green tech airplane should be considerable.

\section{References}

Airbus. (2017). Airbus for Customer. Airbus. Retrieved from http://www.aircraft.airbus.com/tools/airbusfor/customers/

Airbus. (2017). Airbus. Airbus. Retrieved from www.airbus.com

Airbus. (2017). Meeting the next generation of tech pioneers at VivaTech. Airbus xo. Retrieved from http://airbus-xo.com/meeting-next-generation-tech-pioneers-vivatech/

Airbus. (2017). Passenger Airplane. Airbus. Retrieved from http://www.aircraft.airbus.com/aircraftfamilies/passengeraircraft/

Al, M.-C. M. (2007). The Decentralisation of Airbus Production and Services. The Service Industries Journal, 251-262. https://doi.org/10.1080/02642060701207056

Al, W. M. (2010). WTO Dispute Settlement Proceedings: European Support for Airbus in the Spotlight. Intereconomics, 180-187. https://doi.org/10.1007/s10272-010-0334-7

AREND, M. (2017). Airbus Project. SITE SELECTION, 170-172.

Ashford, W. (JULY 2017). Airbus helps secure critical infrastructure. COMPUTERWEEKLY.COM, 4-7.

AsianAviation. (2017). China Southern orders 20 Airbus A350 XWBs. AsianAviation, 1.

AsianAviation. (2017). AIRBUS AND CHINA TO ENHANCE COOPERATION IN AVIATION AND AEROSPACE. AsianAviation, 8. 
AsianAviation. (September 2017). Airbus delivers 100th A350 XWB to China Airlines, names CEO of China centre. AsianAviation, 1.

BANK, T. W. (2017). Air transport, passengers carried. THE WORLD BANK DATA. Retrieved from https://data.worldbank.org/indicator/IS.AIR.PSGR?end=2016\&start=1970\&view=chart

HYPE. CASE STUDY Airbus Creating a Core Innovation Capability. HYPE, 1-36.

IATA. (2013). Airlines Expect $31 \%$ Rise in Passenger Demand by 2017. IATA. https://doi.org/10.1016/S0969-4765(13)70017-1

Joe Tidd, J. B. (2005). MANAGING INNOVATION Integrating Technological, Market and Organizational Change. John Wiley \& Sons Ltd.

MarketLine. (2014). Airbus S.A.S. MarketLine, 1-9.

MarketLine. (2014). The Airbus Group NV (Previously known as European Aeronautic Defence and Space Company [EADS N.V.]). MarketLine, 1-10.

MarketLine. (2015). Airbus Group SE (formerly Airbus Group NV). MarketLine, 1-10.

RESEARCH, B. Product Strategies - The Airbus Narrowbody Move and a Boeing Widebody Opportunity. BERNSTEIN RESEARCH, 71-90.

Southan, J. (2016). 12 TRAVEL TRENDS. BUSINESS TRAVEL ASIA, 52-55.

WALKER, K. (2017). PLANE sailing. ATW, 34-37.

\section{Copyrights}

Copyright for this article is retained by the author(s), with first publication rights granted to the journal.

This is an open-access article distributed under the terms and conditions of the Creative Commons Attribution license which permits unrestricted use, distribution, and reproduction in any medium, provided the original work is properly cited. 